\title{
Creating a safe operating space for wetlands in a changing climate
}

Andy J Green ${ }^{1 *}$, Paloma Alcorlo ${ }^{2}$, Edwin THM Peeters ${ }^{3}$, Edward P Morris ${ }^{4,5}$, José L Espinar ${ }^{1}$, Miguel Angel Bravo-Utrera ${ }^{1}$, Javier Bustamante ${ }^{1}$, Ricardo Díaz-Delgado ${ }^{6}$, Albert A Koelmans ${ }^{3}$, Rafael Mateo ${ }^{7}$, Wolf M Mooij ${ }^{8,3}$, Miguel Rodríguez-Rodríguez ${ }^{9}$, Egbert $\mathrm{H}$ van $\mathrm{Nes}^{3}$, and Marten Scheffer ${ }^{3}$

Many of the world's wetlands may be profoundly affected by climate change over the coming decades. Although wetland managers may have little control over the causes of climate change, they can help to counteract its effects through local measures. This is because direct anthropogenic impacts, such as water extraction and nutrient loading, work in concert with climate change to damage wetlands. Control of these local stressors may therefore ameliorate undesired effects of climate change, such as a shift towards dominance by invasive floating plants, increasingly frequent cyanobacteria blooms, or extinction of key species. Using the iconic Doñana wetlands in Spain as a case study, we illustrate how the concept of creating a "safe operating space" may be implemented to better ensure that ecosystems do not surpass thresholds for collapse during an era of global change.

Front Ecol Environ 2017; doi:10.1002/fee.1459

$F^{r a t a n}$ reshwater wetlands, many of which are global biodiversity hotspots, provide a range of important ecosystem services such as the provision of drinking water and food resources, flood prevention, erosion control, and nutrient retention. However, most wetlands have been destroyed or degraded since 1900 (Davidson 2014), and those that remain are among the most imperiled ecosystems in the world (Strayer and Dudgeon 2010). Their conservation is particularly challenging, requiring coordinated action across complex and often extensive watersheds (Dudgeon et al. 2006).

Although many of the world's most important wetlands are protected, they are still affected by a range of

\section{In a nutshell:}

- Wetlands provide vital services such as water supply or recreation but are often degraded by human activities, such as those that extract freshwater and lead to eutrophication

- Climate change exacerbates this anthropogenic degradation, causing shifts into undesirable states with fewer services

- These synergetic effects can be avoided by reducing existing local impacts and keeping the system within a "safe operating space" where it remains resilient to climate change

- It is vital to identify the thresholds of interacting stressors because once these thresholds are exceeded this will lead to losses in biodiversity and ecosystem services

\footnotetext{
${ }^{1}$ Department of Wetland Ecology, Estación Biológica de Doñana, EBD-CSIC, Sevilla, Spain *(ajgreen@ebd.csic.es); ${ }^{2}$ SocialEcological Systems Laboratory, Department of Ecology, Universidad Autónoma de Madrid, Madrid, Spain; ${ }^{3}$ Department of Aquatic Ecology and Water Quality Management, Wageningen University, Wageningen, the Netherlands; ${ }^{4}$ Department of Ecology and Coastal Management, Instituto de Ciencias Marinas de Andalucía (ICMAN-CSIC), Puerto Real, Spain; continued on last page
}

threats. For example, water extraction and pollution have caused severe degradation of several important wetland ecosystems in spite of their protected status (Panel $1)$. In addition to these local threats, climate change is widely expected to increase the stress on remaining wetlands (Junk et al. 2013). Here, we present a framework for wetlands management that moves beyond the traditional approach of treating each threat in isolation, explicitly recognizing how climate change acts in tandem with other threats, and offering ways to confront and cope with uncertainty, risk, and change in these complex ecosystems. We focus on Doñana in southwest Spain (Panel 2 and Figure 1), an iconic World Heritage Site within the Mediterranean region (Scheffer et al. 2015a), as an example.

\section{The safe operating space concept}

First proposed by Rockström et al. (2009), the concept of a "safe operating space" focused on respecting nine boundaries in order to keep the Earth system in a desired state. A central element of the concept is that many of the Earth system's processes act in a nonlinear way and are sensitive around threshold levels of key variables. If these thresholds are crossed, severe and sometimes irreversible change can occur (eg melting of ice sheets or collapse of monsoon circulations). There is considerable uncertainty in the nature as well as the precise value of such thresholds. This uncertainty is taken into account by defining the boundary of the safe space at a reasonable distance from these thresholds. Recently, the concept of a safe operating space has been adapted as a framework to guide managing ecosystems affected by climate change (Scheffer et al. 2015a). The central idea is that management of local stressors may enhance ecosystem 

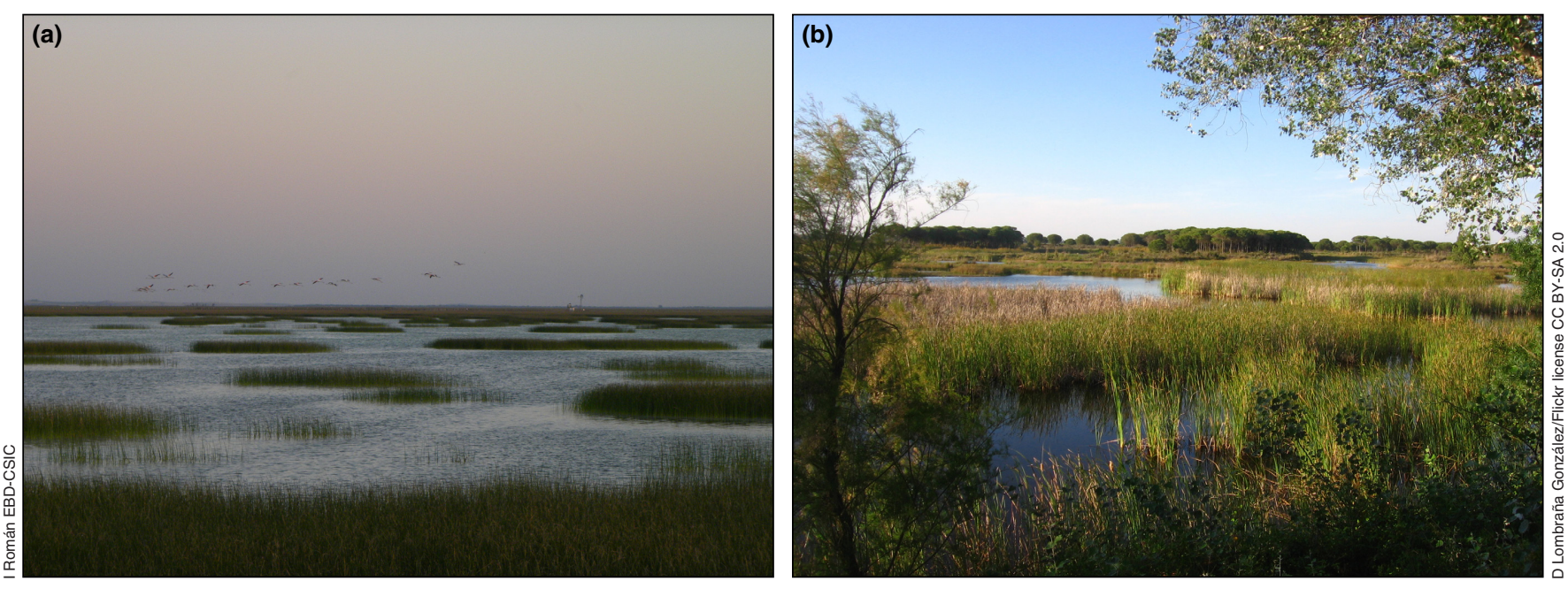

Figure 1. Examples of wetland habitats within Doñana National Park in southwest Spain: (a) marshes and (b) temporary dune ponds.

resilience to reduce the risk of climate change-induced shifts to less desired states that provide fewer ecosystem services (Figures 2 and 3). Various studies (eg Scheffer et al. 2001) suggest that relatively abrupt changes in ecosystem state may be a common phenomenon in wetlands when stressor thresholds are exceeded (Figure 2a). Recognizing these thresholds is key to effective management of wetlands (Kelly et al. 2015).

Scientists' understanding of the response of wetlands to local stressors and their interactions is improving. Often, reducing one local stressor may promote tolerance to another local stressor and, as we will show, may also increase resilience to climate change. Eutrophication and water losses are both local stressors acting synergistically with climate change (see below). As a direct consequence, ecological resilience to the effects of climate change may be enhanced by reducing the negative effects of these local stressors (ie moving from line I to line II in Figure 2b). One implication is that controlling local stressors may allow the creation of a safe operating space in the face of a changing climate (Figure 3). Below, we elaborate on how this framework fits the management of wetlands, using Doñana as a case study.

\section{Interacting stresses on wetlands}

\section{Climate change and nutrient loading}

The combination of nutrient loading and climate warming represents an "allied attack" on wetlands (Moss et al. 2011). Shallow lakes and ponds have welldocumented tipping points where excessive nutrient loading may lead to dominance by blue-green algae (cyanobacteria) or floating plants, triggering losses in biodiversity and ecosystem services (Scheffer 2004). Climate warming also promotes both cyanobacteria and floating plants (Moss et al. 2011; Kosten et al. 2012). Cyanobacteria may be toxic, threatening wildlife as well as drinking water supplies. Floating plants contribute to shading and promote anoxic conditions in the water column, creating a favorable environment for toxic bacteria such as Clostridium (Anza et al. 2014) but an unfavorable one for other aquatic life (Peeters et al. 2013). Both cyanobacteria and floating plants are often considered as symptoms of eutrophication given their association with nutrient loading, but while most floating plants are limited to smaller ponds and sheltered marshes, cyanobacteria will also dominate large open-water systems (Scheffer 2004).

With respect to aquatic invertebrates, eutrophication and higher temperatures work in combination to reduce levels of dissolved oxygen, causing lethal and non-lethal effects (Verberk et al. 2016). Other aspects of climate change, such as increased frequency of extreme events such as storms, can also interact with eutrophication. Nutrient over-enrichment increases the growth rate of scrub vegetation in coastal lagoons but reduces their resistance to damage from hurricanes (Feller et al. 2015).

Paradoxically, the synergy in the "allied attack" from nutrient loading and climate change may offer beneficial options for management. For instance, data from lakes across various climate zones suggest that a 33\% reduction in total nitrogen concentration may offset the increased probability of cyanobacterial dominance expected to result from $1^{\circ} \mathrm{C}$ warming (Kosten et al. 2012). Similarly, a $10-30 \%$ reduction in phosphorus levels may counter the effects of $1^{\circ} \mathrm{C}$ warming during winter on floating plant expansion in temperate regions (Peeters et al. 2013).

In the case of Doñana (Panel 2), situated within the delta of the Guadalquivir River, $80 \%$ of its original marsh surface area has been converted, mainly for agriculture. Agricultural runoff, intense urbanization, inadequate wastewater treatment, and extensive hydrological modifications have led to high nutrient loading to the remaining wetlands (Serrano et al. 2006; Olías et al. 2008; Mendez et al. 2012; Espinar et al. 2015). 


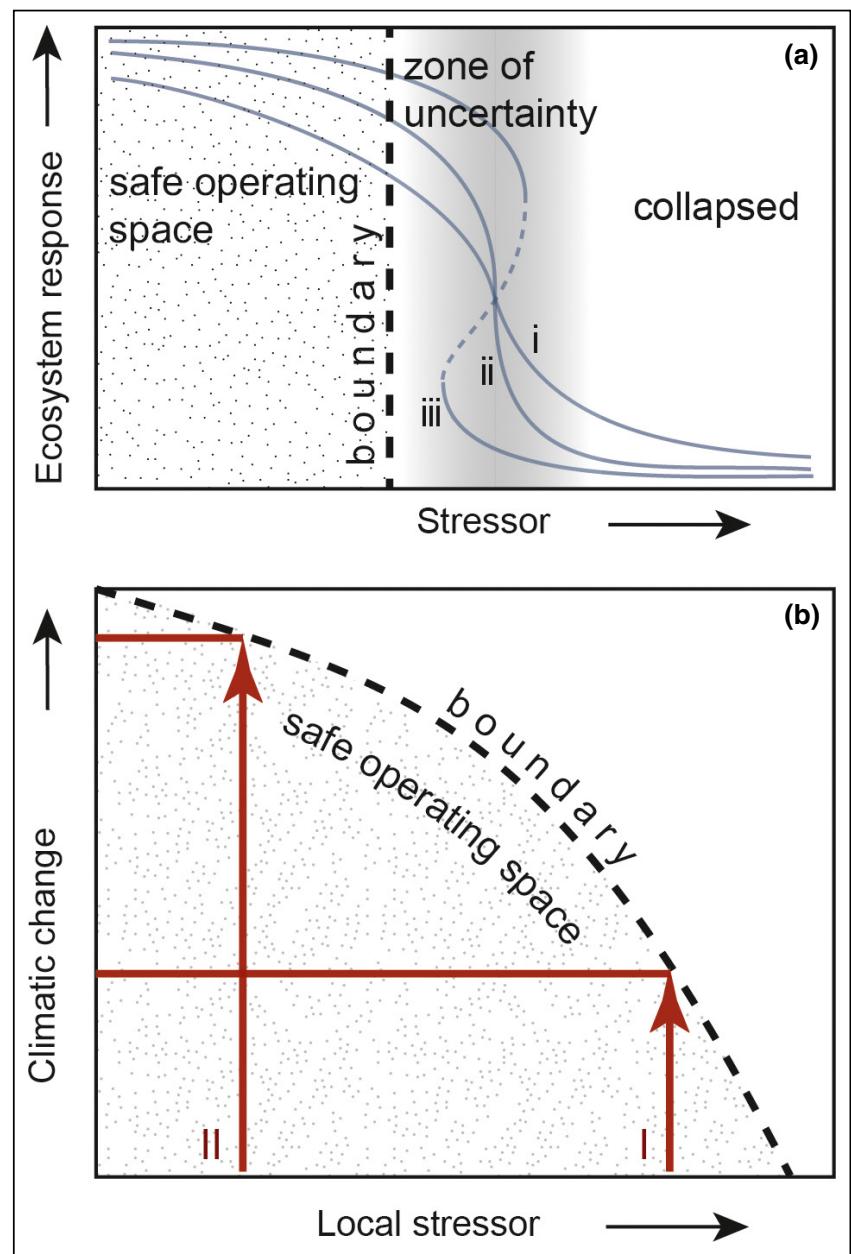

Figure 2. A safe operating space is defined as an area delimited by boundaries with respect to thresholds and uncertainty in the response of an ecosystem to various stressors. (a) Response of an indicator of the state of an ecosystem (eg water clarity) to a stressor (eg nutrient load) can take different forms (eg curves $i$, ii, or iii). The uncertainty in the shape and in the threshold level is accounted for by taking the boundary of the safe operating space at some distance from the best estimate of where the threshold is. (b) The safe level for local stressors can decrease under a different climate (see main text). This implies that the currently safe level for a local stressor (I) should be lowered (II) to ensure that the system stays within the safe operating space. Note that the particular shape of the boundary curve is for illustrative purposes only, and will vary depending on the interactive effects of stressors. Panel (b) is adapted from Figure 1 in Scheffer et al. (2015a).

Higher winter temperatures confer a competitive advantage to floating plants (Peeters et al. 2013), and minimum winter temperatures have increased in Doñana since 1950. The combined increases in temperature and phosphorus loading have enabled the invasion and spread of the alien floating fern Azolla filiculoides since 2001 (Espinar et al. 2015). Similarly, toxins associated with frequent cyanobacterial blooms (Microcystis, Pseudanabaena, and Anabaena) have been implicated in

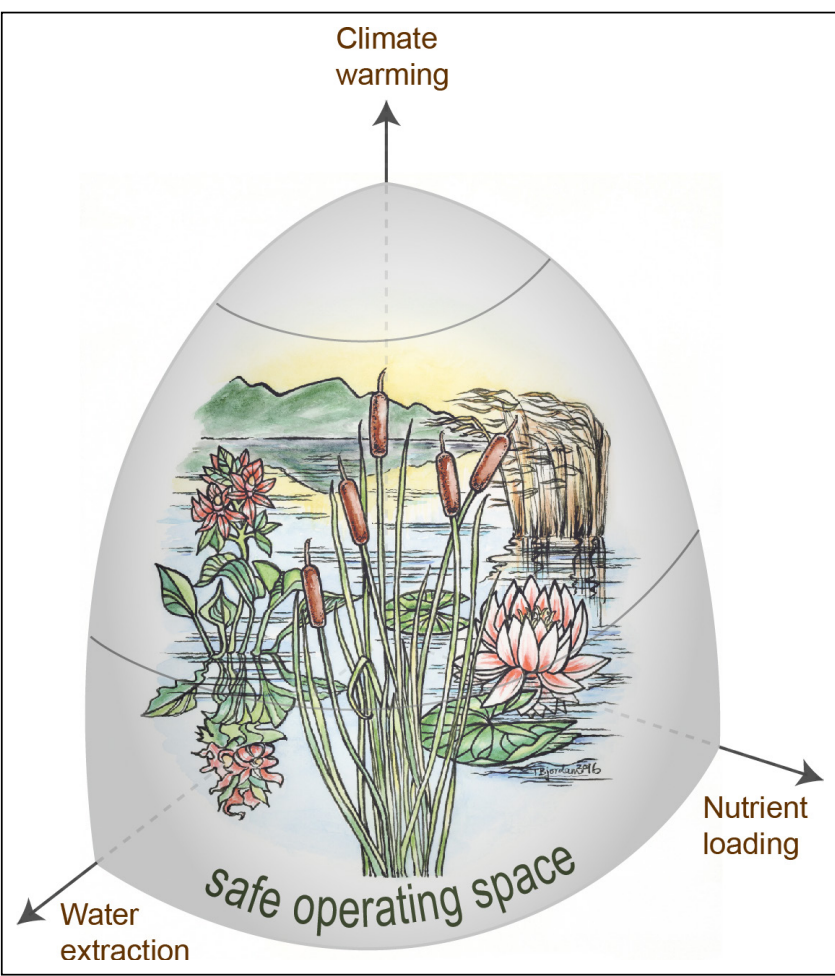

Figure 3. The safe operating space illustrated in three dimensions, reflecting the synergy between water extraction, nutrient loading, and climate warming. To retain the wetland system within the safe operating space to maintain a desirable state as climate change progresses requires reduction of interacting stressors from current levels (indicated by the lower arc that corresponds to position I in Figure 2b) to more strict levels (upper arc corresponding to position II in Figure 2b). We consider Doñana to be currently positioned closer to the lower arc than to the upper one.

mass mortalities of fish and waterbirds, including globally threatened species (López-Rodas et al. 2008). High temperatures and high nutrient loads also jointly contribute to promote conditions conducive to outbreaks of avian botulism, which can have a major impact on waterbirds (Anza et al. 2014); repeated outbreaks have occurred in Doñana (Contreras de Vera et al. 1992).

\section{Climate change and water extraction}

Reduction in groundwater levels and runoff flows in wetlands resulting from water abstraction in the catchment have major impacts on biodiversity and ecosystem functioning. Anoxic conditions, higher temperatures, and increasing salinity affect most species before wetlands dry out completely. Extraction has shortened the hydroperiod (time spent inundated) of many wetlands, causing numerous local extinctions (Panel 1).

The effects of water extraction and a warming climate synergistically result in the loss of many ecosystem services (Figure 4). When subject to climate change, two processes may lead to drying conditions: (1) higher tem- 


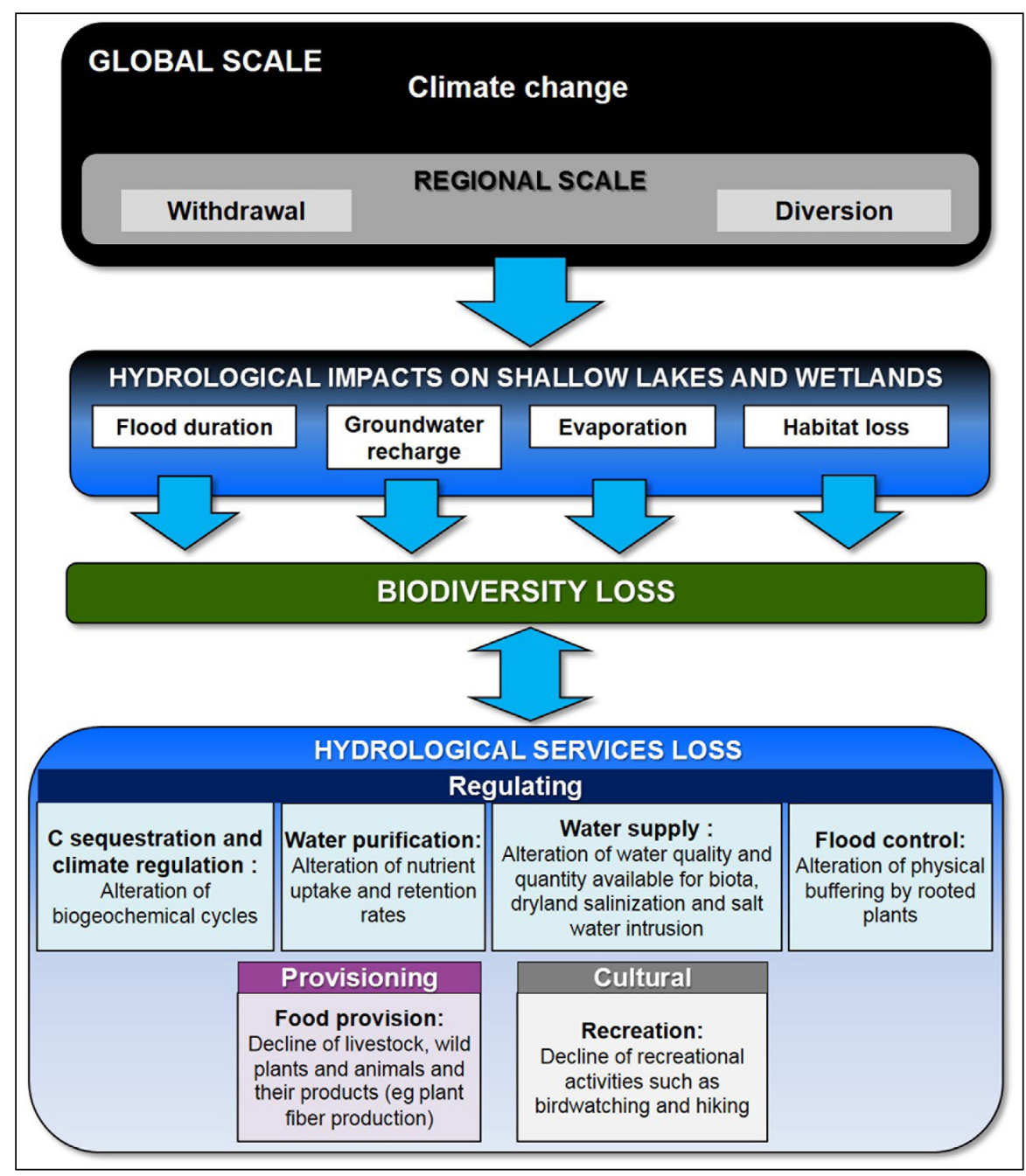

Figure 4. Summary of the synergetic effects of climate change and water extraction and diversion on wetland ecosystem services.

peratures and higher wind velocities increase evapotranspiration as well as evaporation and (2) altered precipitation regimes. Precipitation is projected to increase in higher and moist mid-latitude regions but to decrease in the Mediterranean and other mid-latitude regions, in subtropical arid regions, and in semi-arid regions (Collins et al. 2013). Despite increasing as a result of its spatial distribution, global mean precipitation may not influence global wetland extent as much as warming climatic conditions (Melton et al. 2013). In addition, dry seasons will become drier, even in regions where the mean climate becomes wetter (Kumar et al. 2014). So, for many wetlands, the net result of climate change will be a reduction of available water, which will exacerbate reduced base flows of incoming streams and rivers due to water extraction in the catchment area, and to the lowering of water tables as a result of groundwater extraction.

In the case of Doñana (Panel 2), groundwater extraction for agriculture - including strawberry farms - has reduced flow rates in streams that feed the marsh system by roughly $50 \%$ over the past 20 years (Custodio et al. 2009; Guardiola-
Albert and Jackson 2011) and a decrease in groundwater levels of more than $6 \mathrm{~m}$ in some areas of the aquifer during the same period. Groundwater extraction for an expanding beach resort has also lowered the water table, and the hydroperiod of temporary ponds has been reduced by up to 2 months over a 20-year period (WebPanel 1). Indeed, the reduction in groundwater discharge as a result of abstraction for irrigation and urban supply in recent decades matches the reduction predicted due to climate change this century (GuardiolaAlbert and Jackson 2011). Historical reductions in the hydroperiod have already led to the loss of globally threatened waterfowl that once used the Doñana marshes as a breeding area (Madroño et al. 2004).

\section{Synergetic effects between nutrient loading and water extraction}

Irrespective of climatic change, local stressors will often interact to affect ecosystem functioning. Loss of water through extraction or diversion upstream tends to increase the concentrations of dissolved matter in surface waters, leading to higher concentrations of nutrients and contaminants (especially organic and inorganic persistent pollutants). Water extraction lowers water depth, increases temperatures, and reduces wave action, all of which favor cyanobacteria and floating plants. Thus, the interaction between water loss and eutrophication will enhance the loss of biodiversity and ecosystem services.

In Doñana, reductions in groundwater discharge due to groundwater extraction (Guardiola-Albert and Jackson 2011) have further increased nutrient concentrations in surface waters, promoting cyanobacteria and an Azolla invasion (Espinar et al. 2015). Reduced flow rates and shallower waters also favor expansion of this floating fern.

\section{Dealing with uncertainty}

To establish critical levels for stressors that affect ecosystems, scientists must first comprehensively understand their interactions, feedbacks, and thresholds (Figure 2). Some responses of ecosystems to changing stressors may not have thresholds (Figure 2a); as key variables increase or decrease, there is a gradual decline in services. In many cases the precise character of the response and 


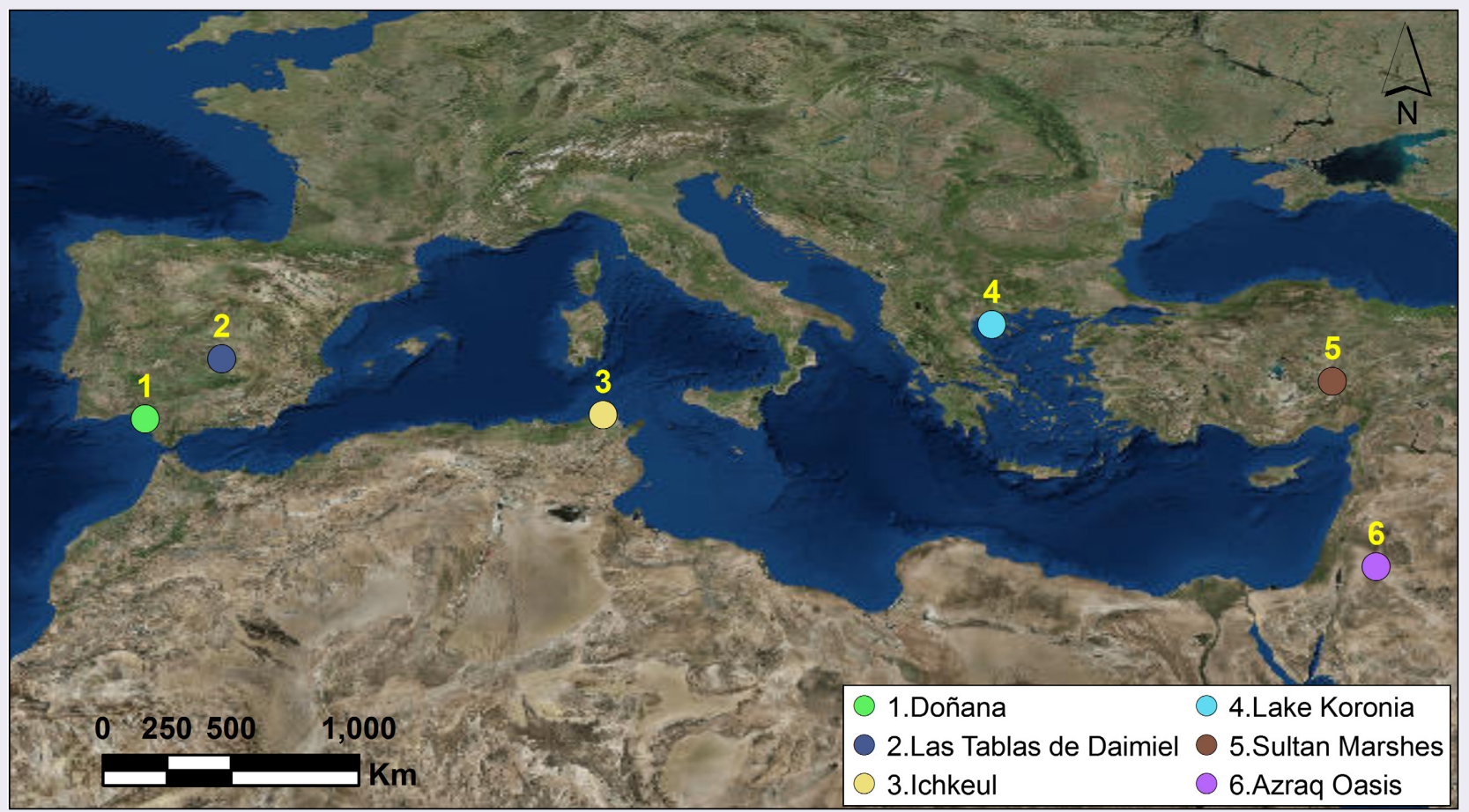

Figure 5. Examples of protected wetlands under threat in the Mediterranean region. Based on an image from Google Earth.

Although wetland degradation occurs in a variety of biogeographical regions, we concentrate on threatened wetlands in the Mediterranean region (Figure 5), where Doñana is located. Information sources are provided in WebTable I.

\section{Tablas de Daimiel in Castilla la Mancha in Spain (Ramsar Site since 1982 and National Park)}

Drainage for cultivation since 1900 and pumping for irrigation since 1960 resulted in the loss of a large floodplain system in central Spain. Tablas de Daimiel is what remains but was mostly dry from the 1980s until 2010, when it switched from a groundwater discharge zone into a recharge zone and experienced underground peat fires. Its hydrology is now semi-artificial, with dams constructed to retain water; during dry periods water is sometimes supplied from other catchment areas via special channels. Water quality has deteriorated severely; six of nine native fish species have been lost, and alien carp have greatly reduced cover of submerged vegetation. Waterbird abundance and diversity have been severely reduced, and major mortalities due to botulism are a frequent event associated with poor water quality. Since 2010 , a series of wet winters has led to some recovery of groundwater levels.

\section{Lac Ichkeul in Tunisia (Ramsar Site since I 980, National} Park and UNESCO World Heritage Site)

This lake has been seriously affected by hydrological changes in the five main inflowing rivers, four of which have been dammed since 1984 , reducing inputs to the lake by up to $75 \%$. In the past, water flowed from the lake to the sea; however, after these hydrological changes, seawater often flowed into the lake during dry periods. As a result, salinity increased to $37 \mathrm{~g} \mathrm{~L}^{-1}$ in summer, causing a major reduction in the cover of dominant vegetation (Potamogeton and Scirpus). Subsequently, the number of wintering waterfowl - for which this site was largely protected - was reduced by one-half, with even greater reductions in herbivorous waterfowl. In recent years, there has been partial recovery due to provision of minimal outflows from upstream dams, and effective management of a sluice gate connecting the lake with the sea.

\section{Lake Koronia in Greece (Ramsar Site since 1975)}

Since 1975, excessive groundwater extraction for irrigation and industrial purposes has shifted the lake - once the fourth largest in Greece - to a negative water balance. Surface area decreased from 47 to $17 \mathrm{~km}^{2}$ and maximum depth dropped from 8.5 to $0.8 \mathrm{~m}$. Nutrient inputs from agriculture and industry caused hypertrophy, and the lake has shifted from autotrophy to heterotrophy with massive cyanobacterial blooms. Fish and piscivorous birds were eliminated by 2004 . Major waterbird mortality events are now common.

\section{Azraq Oasis in Jordan (Ramsar Site since 1977)}

The Azraq Oasis formerly covered up to $26 \mathrm{~km}^{2}$ and was the most important wetland in the region, with 350,000-500,000 wintering waterfowl. It was sustained by a large basalt aquifer and by winter rains. Groundwater pumping for irrigation and to supply the capital city Amman began in 1963 but escalated during the 1980s and 1990s, causing the water table to drop by about $25 \mathrm{~m}$, with rapid wetland shrinkage. Previously permanent pools and marshes dried out completely in 1990 
Panel 1. Continued.

and 1994, when most aquatic vegetation was lost. Many waterbird species have gone extinct. Four of eight fish species have gone extinct in the wild, including the endemic Aphanius sirhani. Collapse of the ecosystem had a major impact on tourism, agriculture, and the local communities. After a restoration project began in 1994, 10\% of the original water input was returned by reverse pumping, reflooding less than $20 \%$ of the original wetland.

Sultansazligi in Turkey (Ramsar Site since 1994, Wildlife Reserve since 197I)

The Sultan Marshes covered $176 \mathrm{~km}^{2}$ including two lakes. Groundwater pumping, direct extraction of water from the lakes, and construction of three dams in the catchment area have caused rapid degradation since 1988, with a major decline in water quality due to fertilizers and pesticides. Infrastructure was created to irrigate a total of 525 $\mathrm{km}^{2}$. Drastic hydrological changes have led to the drainage of freshwater into the saline lake, and the drainage of saline water into the freshwater marshes. From 1980 to 2003 , lake areas declined by $93 \%$ and marsh areas declined by over $50 \%$, with the entire wetland system drying out in 1990-199| and 2000-2002. Waterbird populations have collapsed, and breeding populations of the globally threatened marbled teal and white-headed duck have disappeared. the positions of possible thresholds are uncertain. Occasionally, even the key stressors threatening the system may be unknown, such as when pharmaceutical contaminants from runoff or wastewater accumulate in aquatic ecosystems (Arnold et al. 2014). Often, different stressors and their thresholds interact in ways that are as yet not fully understood. The toxicity of aquatic contaminants such as metals or pesticides varies strongly with temperature in laboratory settings. Little is known about these effects in the field, where there is usually an assortment of multiple contaminants likely to interact, although "chemical footprinting" is a feasible means of identifying safe boundaries (Posthuma et al. 2014).
Clearly, the combination of uncertainty and the complexity of potential interactions make thresholds dynamic and challenging to anticipate or monitor.

Despite being one of the most studied ecosystems in Spain, Doñana is no exception when it comes to uncertainty in its response to climate change and other stressors (WebPanel 1). However, action is undoubtedly needed to reduce water extraction and nutrient loading to avoid ecosystem collapse under predicted climatechange scenarios. For many other protected wetlands around the world, uncertainty will be relatively greater because monitoring activities are often limited (eg restricted to waterbird counts).

\section{Panel 2. Major threats to iconic wetland ecosystems - the example of Doñana}

Doñana National Park (DNP) is a UNESCO World Heritage Site at the center of one of the most important wetland complexes in Europe (WebPanel 2), in the delta of the Guadalquivir River in southwest Spain. Although covering 54,252 ha, the DNP is associated with a 260,000 -ha hydrological catchment (Figure 6).

The DNP contains what remains of a larger seasonal marsh system known as the "marismas del Guadalquivir", formed in a similar manner to the Mississippi River delta but on a smaller scale; as siltation filled the gaps between dynamic river channels or levees with impermeable clay, there was a transition from a tidal marsh to a pluvial and fluvial marsh. More than $80 \%$ of the original marsh surface area has been transformed since 1920 (Mendez et al. 2012). The marsh is fed by direct precipitation and surface runoff from a network of seasonal streams and is relatively isolated from the main Guadalquivir River. Given the hot, dry summers, evapotranspiration rates greatly exceed precipitation for much of the year, and the marshes dry out from July until rains arrive in autumn or early winter.To the southwest, the marshes are separated from the Atlantic Ocean only by a major deposit of aeolian sands, including a mobile dune system (Figure 6). These sands contain 3000 temporary ponds (WebPanels I and 2). Both the marshes and dune ponds are under severe threat from human activities in the surrounding areas.

Streams feeding the marsh are dependent on groundwater discharge, which has declined markedly in the past 30 years due to the drilling of wells to supply strawberry and other farms. Within the park's catchment area, unlicensed greenhouses occupy more than 6000 ha and there are over 1000 illegal groundwater-extracting wells. Flow rates entering the marsh from the most important stream (the Rocina) declined by $50 \%$ in two decades as a result of groundwater extraction (Guardiola-Albert and Jackson 20II). Extraction rates are $90 \mathrm{hm}^{3}$ (cubic hectometers) per year on average, representing $45 \%$ of the total aquifer recharge (Custodio et al. 2009).

Pollution has increased due to urbanization within the catchment area, and seasonal influxes of agricultural workers have contributed to greater inputs of wastewater to the streams.

Surrounding marshes have been drained and converted to grow rice, cereals, or sunflowers, while many of the streams that fed the remaining marshes have been diverted. Phosphorus loads from the catchment have increased in the past 20 years (WebFigure 3) owing to urban and agricultural runoff, facilitating an invasion of the alien fern Azolla filiculoides (Figure 6). Doñana is also threatened by metal pollution resulting from intense mining activity in mountains to the north since ancient Roman times, and especially since a mine spill in 1998 (Mendez et al. 2012).

Expansion of Matalascañas beach resort (created in the 1960s) exacerbates overextraction of groundwater. New highways and golf courses have increased visitor numbers and extraction levels. The closest DNP ponds lie $600 \mathrm{~m}$ from this resort, and by the year 2000 two of them had dried out as groundwater levels dropped (Serrano and Zunzunegui 2008). 


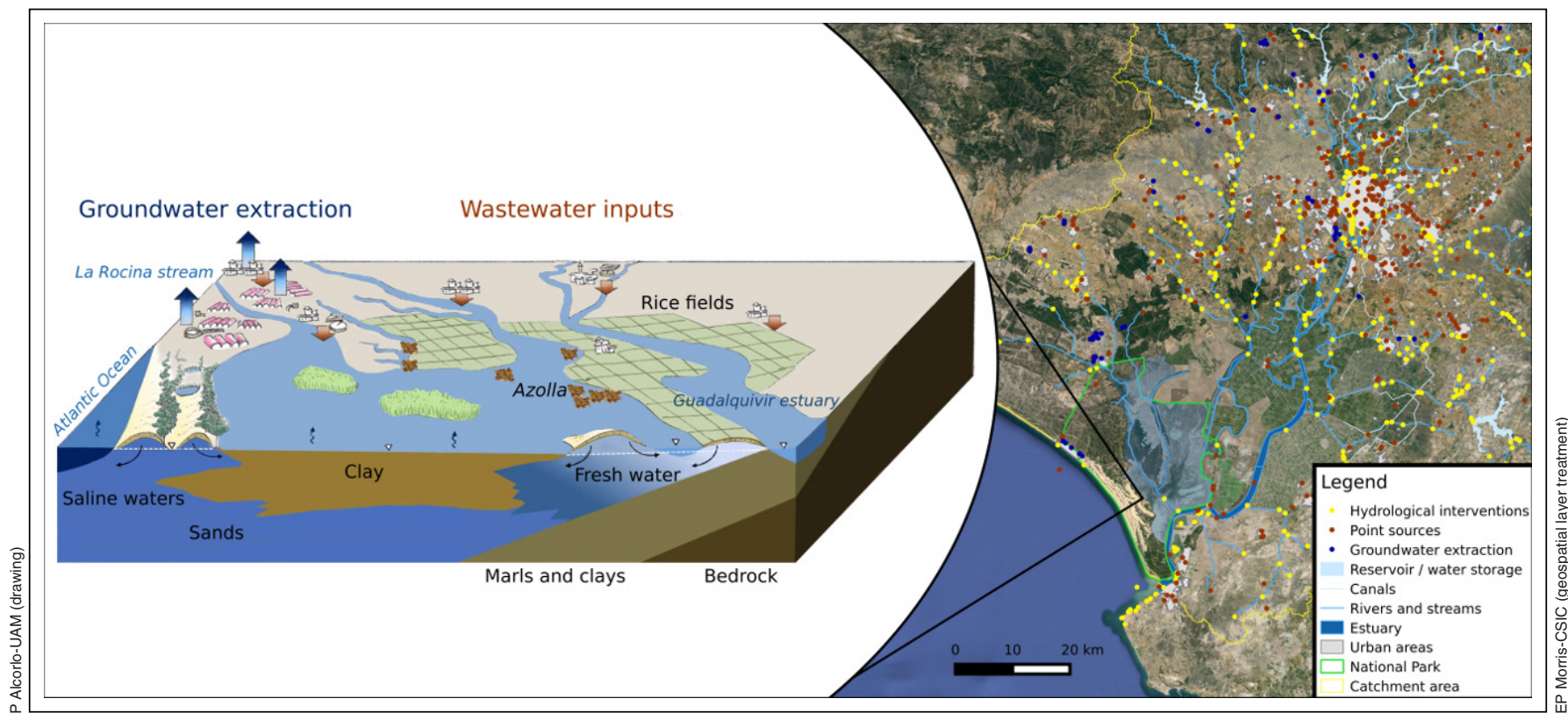

Figure 6. Schematic drawing of the wetlands in Doñana National Park and major associated threats. The three-dimensional crosssection on the left moves inland from the Atlantic Ocean, through sand dunes holding aquifer-fed ponds, and into the marshes over impermeable clay. It highlights the impacts of groundwater extraction for strawberry farms (in pink) and urban use, and point sources of nutrients from wastewater plants. The image on the right provides details of major impacts throughout the catchment area of the Doñana wetlands. Hydrological interventions include any artificial structure or action that alters the local surface water hydrology, such as dams or diversion for agriculture. Point inputs of nutrients or pollutants include urban, industrial, agriculture, and aquaculture sources. Based on an image from Google Maps and geospatial layers available at www.chguadalquivir.es/inicio.

As climate change is projected further into the future, there is greater uncertainty about its rate and characteristics as well as the effects of stressors such as water extraction or nutrient loading. For wetlands, the uncertainties related to changes in precipitation are particularly important. In southern Europe, for example, most climatic models predict decreases in precipitation, which will intensify threats from competing water demands, but some models predict increases (Nieto and Rodriguez-Puebla 2006). Although highly uncertain, the rate of projected sea-level rise will have important consequences for coastal wetlands such as Doñana. In addition, when considering the boundaries of the safe operating space for wetlands, an increased likelihood of extreme climatic events such as droughts or hurricanes adds to this uncertainty.

As a precaution, in light of this inherent uncertainty, the boundaries of the safe operating space should be defined well below estimates of critical thresholds for key variables (Figure 2a). To maintain ecosystems - even those under the influence of climate change - within this space, managers should create objectives that strictly adhere to these boundaries (Figures $2 \mathrm{~b}$ and 3 ).

\section{Implications for research, monitoring, and management}

Implementing management through the safe operating space concept will require radical changes in existing research and monitoring programs. To date, research is mostly focused on understanding the effect of single stressors. For instance, although a current EU European Framework Directive defines safe maximum concentrations of nutrients and pollutants in freshwater systems (Sánchez-Montoya et al. 2012), scientists need to understand how different stressors interact. Preliminary research is starting to reveal important interactions, but a systematic effort - including adjusting the focus of experimental studies and re-examining numerous existing datasets - will be necessary to map critical levels of interacting stressors.

Meanwhile, monitoring programs should be redesigned to ascertain how far the system is from critical transitions such as a shift to dominance by cyanobacteria or floating plants. In addition to classical monitoring of species abundances and abiotic conditions, scientists should monitor indicators of resilience. Across complex systems, emerging studies are demonstrating how the distance to a threshold is reflected in generic alterations of spatial and temporal patterns, reflecting loss of resilience (Pace et al. 2015; Scheffer et al. 2015b). These methods make use of high-resolution time series and spatial information that was once difficult to obtain, but can now be collected relatively inexpensively using automated sensors and satellite-based data. In the future, we expect further tools to be developed, such as e-DNA.

The challenges of managing a safe operating space go beyond technical issues alone. Wetlands are part of a complex interconnected social-ecological system. 
Successful management of such systems requires flexible governance structures and institutions with the capacity to adapt to change (Hughes et al. 2007; Palomo et al. 2014). An adaptive governance framework - one that enables and supports collaborations among scientists, other stakeholders, communities, and government agencies - must be pursued. A shift is required from conventional top-down management approaches (currently dominant in the Mediterranean region and elsewhere) to adaptive governance based on four key components (Hughes et al. 2007): (1) a sound understanding of ecosystem dynamics, (2) a flexible approach that treats policies as testable hypotheses and management interventions as experiments, (3) adaptable institutions that support social networks, (4) a built-in capacity to address change and confront uncertainty.

In Doñana since 1920, both water resources and wetland conservation have been managed by rigid institutions with a similar top-down approach and a focus on civil engineering works and charismatic megafauna (Mendez et al. 2012). Innovative change is required to develop a more flexible and adaptive institutional regime, while a refocus of research and monitoring approaches is needed to provide the scientific basis for the safe operating space approach.

\section{Conclusions}

As illustrated by the Doñana case study, wetlands can be threatened by local stressors that - together with the effects of a changing climate - collectively erode ecosystem resilience. Although local or national agencies cannot single-handedly mitigate climate change, they have the option to build a safe operating space for Doñana and other wetlands subject to changing conditions. Decisions from informed policy makers can promote ecosystem resilience to global threats through local measures. Ecologists can help to frame the perspective of a safe operating space for threatened ecosystems by adopting a more action-oriented approach to outreach that may resonate with a broader audience.

\section{Acknowledgements}

AJG was supported by a WIMEK grant for a research stay at WUR. EPM was supported by a JAE DOCTORES 2010 contract funded by the European Union (European Social Fund, ESF2007-2013) and the Spanish Ministry for Economy and Competitiveness, as well as the EU FP7 project FAST (grant 607131). Funding was also provided by the European Union's Horizon 2020 research and innovation program under grant agreement number 641762 to the ECOPOTENTIAL project. C Perennou provided helpful comments on earlier versions of the manuscript. Maps were made using data from CHGuadalquivir (www.chguadalquivir.es/ide) with QGIS (www.qgis.org) and the Google Maps API.

\section{References}

Anza I, Vidal D, Laguna C, et al. 2014. Eutrophication and bacterial pathogens as risk factors for avian botulism outbreaks in wetlands receiving effluents from urban wastewater treatment plants. Appl Environ Microb 80: 4251-59.

Arnold KE, Brown AR, Ankley GT, et al. 2014. Medicating the environment: assessing risks of pharmaceuticals to wildlife and ecosystems. Philos T R Soc B 369: 20130569.

Collins M, Knutti R, Arblaster JM, et al. 2013. Long-term climate change: projections, commitments and irreversibility. In: Stocker TF, Qin D, Plattner GK, et al. (Eds). Climate change 2013: the physical science basis. Contribution of Working Group I to the Fifth Assessment Report of the Intergovernmental Panel on Climate Change. Cambridge, UK: Cambridge University Press.

Contreras de Vera A, León Vizcaíno L, Cubero Pablo MJ, et al. 1992. Occurrence of Clostridium botulinum in wetlands of the Guadalquivir River basin, Spain. Épidémiologie et Santé Animale 21: 39-49.

Custodio E, Manzano M, and Montes C. 2009. Las aguas subterráneas en Doñana: aspectos ecológicos y sociales. Sevilla, Spain: Agencia Andaluza del Agua, Consejería de Medio Ambiente.

Davidson NC. 2014. How much wetland has the world lost? Longterm and recent trends in global wetland area. Mar Freshwater Res 65: 934-41.

Dudgeon D, Arthington AH, Gessner MO, et al. 2006. Freshwater biodiversity: importance, threats, status and conservation challenges. Biol Rev 81: 163-82.

Espinar JL, Díaz-Delgado R, Bravo-Utrera MA, et al. 2015. Linking Azolla filiculoides invasion to increased winter temperatures in the Doñana marshland (SW Spain). Aquat Invasions 10: 17-24.

Feller IC, Dangremond EM, Devlin DJ, et al. 2015. Nutrient enrichment intensifies hurricane impact in scrub mangrove ecosystems in the Indian River Lagoon, Florida, US. Ecology 96: 2960-72.

Guardiola-Albert C and Jackson CR. 2011. Potential impacts of climate change on groundwater supplies to the Doñana wetland, Spain. Wetlands 31: 907-20.

Hughes TP, Gunderson LH, Folke C, et al. 2007. Adaptive management of the Great Barrier Reef and the Grand Canyon World Heritage Areas. Ambio 36: 586-92.

Junk WJ, An SQ, Finlayson CM, et al. 2013. Current state of knowledge regarding the world's wetlands and their future under global climate change: a synthesis. Aquat Sci 75: 151-67.

Kelly RP, Erickson AL, Mease LA, et al. 2015. Embracing thresholds for better environmental management. Philos $T R$ Soc $B$ 370: 20130276.

Kosten S, Huszar VLM, Becares E, et al. 2012. Warmer climates boost cyanobacterial dominance in shallow lakes. Global Change Biol 18: 118-26.

Kumar S, Lawrence DM, Dirmeyer PA, et al. 2014. Less reliable water availability in the 21 st century climate projections. Earth's Future 2: 152-60.

López-Rodas V, Maneiro E, Lanzarot MP, et al. 2008. Mass wildlife mortality due to cyanobacteria in the Doñana National Park, Spain. Vet Rec 162: 317-18.

Madroño A, González GG, and Atienza JC (Eds). 2004. Libro rojo de las Aves de España. Madrid, Spain: Organismo Autónomo Parques Nacionales.

Melton JR, Wania R, Hodson EL, et al. 2013. Present state of global wetland extent and wetland methane modelling: conclusions from a model inter-comparison project (WETCHIMP). Biogeosciences 10: 753-88.

Mendez PF, Isendahl N, Amezaga JM, et al. 2012. Facilitating transitional processes in rigid institutional regimes for water management and wetland conservation: experience from the Guadalquivir estuary. Ecol Soc 17: 26. 
Moss B, Kosten S, Meerhoff M, et al. 2011. Allied attack: climate change and eutrophication. Inland Waters 1: 101-05.

Nieto S and Rodriguez-Puebla C. 2006. Comparison of precipitation from observed data and general circulation models over the Iberian Peninsula. J Climate 19: 4254-75.

Olías M, González F, Cerón JC, et al. 2008. Water quality and distribution of trace elements in the Doñana aquifer (SW Spain). Environ Geol 55: 1555-68.

Pace ML, Carpenter SR, and Cole JJ. 2015. With and without warning: managing ecosystems in a changing world. Front Ecol Environ 13: 460-67.

Palomo I, Montes C, Martín-López B, et al. 2014. Incorporating the social-ecological approach in protected areas in the Anthropocene. BioScience 64: 181-91.

Peeters ETHM, van Zuidam JP, van Zuidam BG, et al. 2013. Changing weather conditions and floating plants in temperate drainage ditches. J Appl Ecol 50: 585-93.

Posthuma L, Bjorn A, Zijp MC, et al. 2014. Beyond safe operating space: finding chemical footprinting feasible. Environ Sci Technol 48: 6057-59.

Rockström J, Steffen W, Noone K, et al. 2009. A safe operating space for humanity. Nature 461: 472-75.

Sánchez-Montoya MM, Arce MI, Vidal-Abarca MR, et al. 2012. Establishing physico-chemical reference conditions in Mediterranean streams according to the European Water Framework Directive. Water Res 46: 2257-69.

Scheffer M. 2004. Ecology of shallow lakes. London, UK: Chapman and Hall.

Scheffer M, Barrett S, Carpenter SR, et al. 2015a. Creating a safe operating space for iconic ecosystems. Science 347: 1317-19.

Scheffer M, Carpenter SR, Dakos V, et al. 2015b. Generic indicators of ecological resilience. Annu Rev Ecol Evol Syst 46: $145-67$.
Scheffer M, Carpenter S, Foley JA, et al. 2001. Catastrophic shifts in ecosystems. Nature 413: 591-96.

Serrano L and Zunzunegui M. 2008. The relevance of preserving temporary ponds during drought: hydrological and vegetation changes over a 16-year period in the Doñana National Park (south-west Spain). Aquat Conserv 18: 261-79.

Serrano L, Reina M, Martín G, et al. 2006. The aquatic systems of Doñana (SW Spain): watersheds and frontiers. Limnetica 25: $11-32$.

Strayer DL and Dudgeon D. 2010. Freshwater biodiversity conservation: recent progress and future challenges. J N Am Benthol Soc 29: 344-58.

Verberk WC, Durance I, Vaughan IP, et al. 2016. Field and laboratory studies reveal interacting effects of stream oxygenation and warming on aquatic ectotherms. Global Change Biol 22: 1769-78.

\section{Supporting Information}

Additional, web-only material may be found in the online version of this article at http://onlinelibrary. wiley.com/doi/10.1002/fee.1459/suppinfo

${ }^{5}$ Department of Biology, Facultad de CC del Mar y Ambientales, CEI·MAR - Universidad de Cádiz, Puerto Real, Spain; ${ }^{6}$ Remote Sensing Laboratory, Estación Biológica de Doñana, EBD-CSIC, Sevilla, Spain; ${ }^{7}$ Instituto de Investigación en Recursos Cinegéticos, IREC (CSIC, UCLM, JCCM), Ciudad Real, Spain; ${ }^{8}$ Department of Aquatic Ecology, Netherlands Institute of Ecology, Wageningen, the Netherlands; ${ }^{9}$ Department of Physical, Chemical, and Natural Systems, Universidad Pablo de Olavide, Seville, Spain 


\section{WebPanel 1. Key uncertainties about how the Doñana ecosystem functions and where critical thresholds for stressors are situated}

\section{Hydroperiod in the marsh}

Owing to hot, dry summers, evapotranspiration rates greatly exceed precipitation for much of the year, and the Doñana marshes dry out completely from July until rains arrive in the autumn and winter (Serrano et al. 2006). The hydroperiod within the extensive shallow marsh system is highly variable across space and time, being much shorter in drier years or when rains arrive late (WebFigure 1). Hydroperiods were longer historically (García-Novo and Marín 2005), but there has been no significant change in hydroperiod in recent decades (Bustamante et al. 2013), despite reductions in flow rates in the entry streams due to groundwater extraction and an increase in mean temperatures during winter and spring over the past 60 years (Espinar et al. 2015). It is unclear at what point further reduction in flow rates and/or increases in evapotranspiration rates will lead to a shortening of hydroperiods, but modeling exercises with future climatic scenarios suggest this will happen (Guardiola-Albert and Jackson 2011). Current groundwater extraction must be reduced to compensate for ongoing climate change and maintain groundwater discharge to the entry streams, but by how much? As projected temperatures increase, so does the degree of uncertainty in existing hydrological models of Doñana and their assumptions about rates of aquifer recharge and discharge, evaporation rates in the wetlands, and changes to human behavior (Guardiola-Albert and Jackson 2011). Measures required to secure future groundwater supplies need to take into account strong time lags that can delay impacts on the aquifer after over-extraction for up to 60 years, as a result of slow rates of circulation within the aquifer (Custodio et al. 2009). Future hydroperiods also depend on changing interactions between the marsh and the Guadalquivir estuary as sea-levels rise in the Atlantic Ocean, and on plans for restoration of other entry streams diverted decades ago.

\section{Desiccation of the dune ponds}

One dune pond is permanent and many have hydroperiods of over 5 months (WebFigure 2), but their mean hydroperiods have declined by 2 months over 20 years and some ponds no longer flood, probably due to groundwater extraction (Gómez-Rodríguez et al. 2010). The shortening hydroperiods will have a major impact on metapopulations of amphibians, invertebrates, and plants that rely on the more permanent ponds as a refuge during drier years, enabling recolonization of other ponds when they reflood. If hydroperiods continue to shorten, at some unknown point the metapopulations will go extinct. Modelling has shown that the observed spatial structure of the temporary ponds network is more robust to drought than similar random structures, allowing amphibians to move more easily between flooded ponds and increasing the probability of reproduction in dry years (Fortuna et al. 2006).

\section{Eutrophication}

Increases in $\mathrm{P}$ inputs to the marsh via the entry streams have been dramatic (WebFigure 3), but owing to incomplete stream discharge data it is uncertain how much of this increase is due to concentration as flow rates declined. How much agricultural and urban $\mathrm{P}$ sources are responsible for this increase has not been established in detail. Atmospheric sources may also be partly responsible (Castillo et al. 2013; Gonzalez-Castanedo et al. 2015). The invasion of floating mats of Azolla since 
2001 (Espinar 2006; García-Murillo et al. 2007) in an area traditionally covered by dense meadows of native, submerged macrophytes (Espinar 2006) indicates that a safe boundary has already been exceeded. Measures are urgently needed to reduce orthophosphate concentrations to below $0.2 \mathrm{mg} \mathrm{L}^{-}$

${ }^{1}$ (eg improving all wastewater treatment plants to meet the standards of the EU Urban Waste Water Treatment Directive) but it is not clear whether that would be enough to prevent Azolla expansion and harmful algal blooms, both of which have also been linked to climate change (Baez et al. 2014; Espinar et al. 2015). P concentrations have also increased in marsh sediments (García et al. 2007) from where they may be released back into the water column, potentially maintaining high $\mathrm{P}$ concentrations even if stream inputs are successfully reduced.

\section{WebReferences}

Baez JC, Real R, Lopez-Rodas V, et al. 2014. The North Atlantic Oscillation and the Arctic Oscillation favour harmful algal blooms in SW Europe. Harmful Algae 39: 121-26.

Bustamante J, DíazDelgado R, Aragonés D, et al. 2013. Proyecto HYDRA: aplicación de la teledetección al estudio de la dinámica hídrica y de la vegetación acuática en las marismas de Doñana. XV Congreso de la Asociación Española de Teledetección; 22-24 Oct 2013; Torrejón de Ardoz (Madrid): Instituto Nacional de Técnica Aeroespacial.

Castillo S, Jesús D, de la Campa AMS, et al. 2013. Heavy metal deposition fluxes affecting an Atlantic coastal area in the southwest of Spain. Atmos Environ 77: 509-17.

Custodio E, Manzano M, and Montes C. 2009. Las aguas subterráneas en Doñana: aspectos ecológicos y sociales. Sevilla, Spain: Agencia Andaluza del Agua, Consejería de Medio Ambiente.

Espinar JL. 2006. The importance of sample size for the detection of a biomass-diversity pattern in Mediterranean wetlands. J Veg Sci 17: 227-32.

Espinar JL, Díaz-Delgado R, Bravo-Utrera MA, et al. 2015. Linking Azolla filiculoides invasion to increased winter temperatures in the Doñana marshland (SW Spain). Aquat Invasions 10: 1724.

Florencio M, Diaz-Paniagua C, Gomez-Rodriguez C, et al. 2014. Biodiversity patterns in a macroinvertebrate community of a temporary pond network. Insect Conserv Divers 7: 4-21.

Fortuna MA, Gomez-Rodriguez C, and Bascompte J. 2006. Spatial network structure and amphibian persistence in stochastic environments. P R Soc B 273: 1429-34.

García LV, Gutiérrez González E, Espinar JL, et al. 2007. Cambios edáficos en las marismas de Doñana y su relación con la invasión de Azolla filiculoides. Proceedings III simposio sobre control de la degradación de suelos y la desertificación; 16-20 Sep 2007; Laguna, Tenerife: Departamento de Edafología y Geología, Universidad de La Laguna.

García-Murillo P, Fernandez-Zamudio R, Cirujano S, et al. 2007. The invasion of Doñana National Park (SW Spain) by the mosquito fern (Azolla filiculoides Lam). Limnetica 26: 243-50.

García-Novo F and Marín C. 2005. Doñana, water and biosphere. Madrid, Spain: Confederación Hidrográfica del Guadalquivir, Ministerio de Medio Ambiente. http://issuu.com/pubcipriano/docs/donanawaterandbiosphere_2005_.

Gómez-Rodríguez C, Bustamante J, and Díaz-Paniagua C. 2010. Evidence of hydroperiod shortening in a preserved system of temporary ponds. Remote Sensing 2: 1439-62.

Gonzalez-Castanedo Y, Sanchez-Rodas D, de la Campa AMS, et al. 2015. Arsenic species in atmospheric particulate matter as tracer of the air quality of Doñana Natural Park (SW Spain). Chemosphere 119: 1296-303.

Guardiola-Albert C and Jackson CR. 2011. Potential impacts of climate change on groundwater supplies to the Doñana wetland, Spain. Wetlands 31: 907-20.

Serrano L, Reina M, Martín G, et al. 2006. The aquatic systems of Doñana (SW Spain): watersheds and frontiers. Limnetica 25: 11-32. 


\section{AJ Green et al. - Supporting Information}
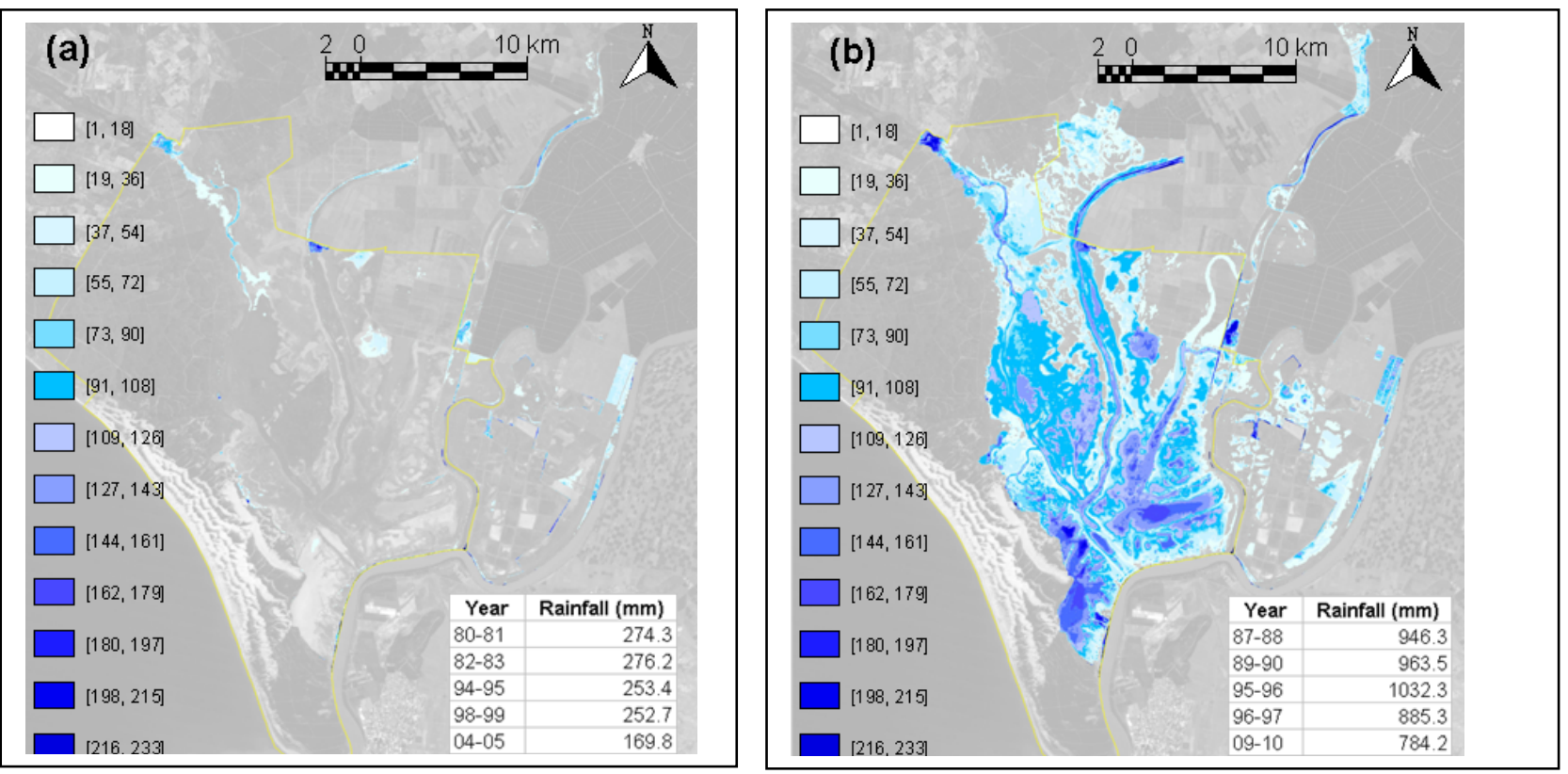

WebFigure 1. Summary of hydroperiods in the Doñana marshes from 1980 to 2014. Mean number of days flooded during the five driest (a) and five wettest (b) years are indicated. The yellow line marks the boundary of Doñana National Park. The background image is a Landsat TM image from June 1999 radiometrically corrected by the Remote Sensing Laboratory of the Estación Biológica de Doñana (LAST-EBD). 


\section{AJ Green et al. - Supporting Information}
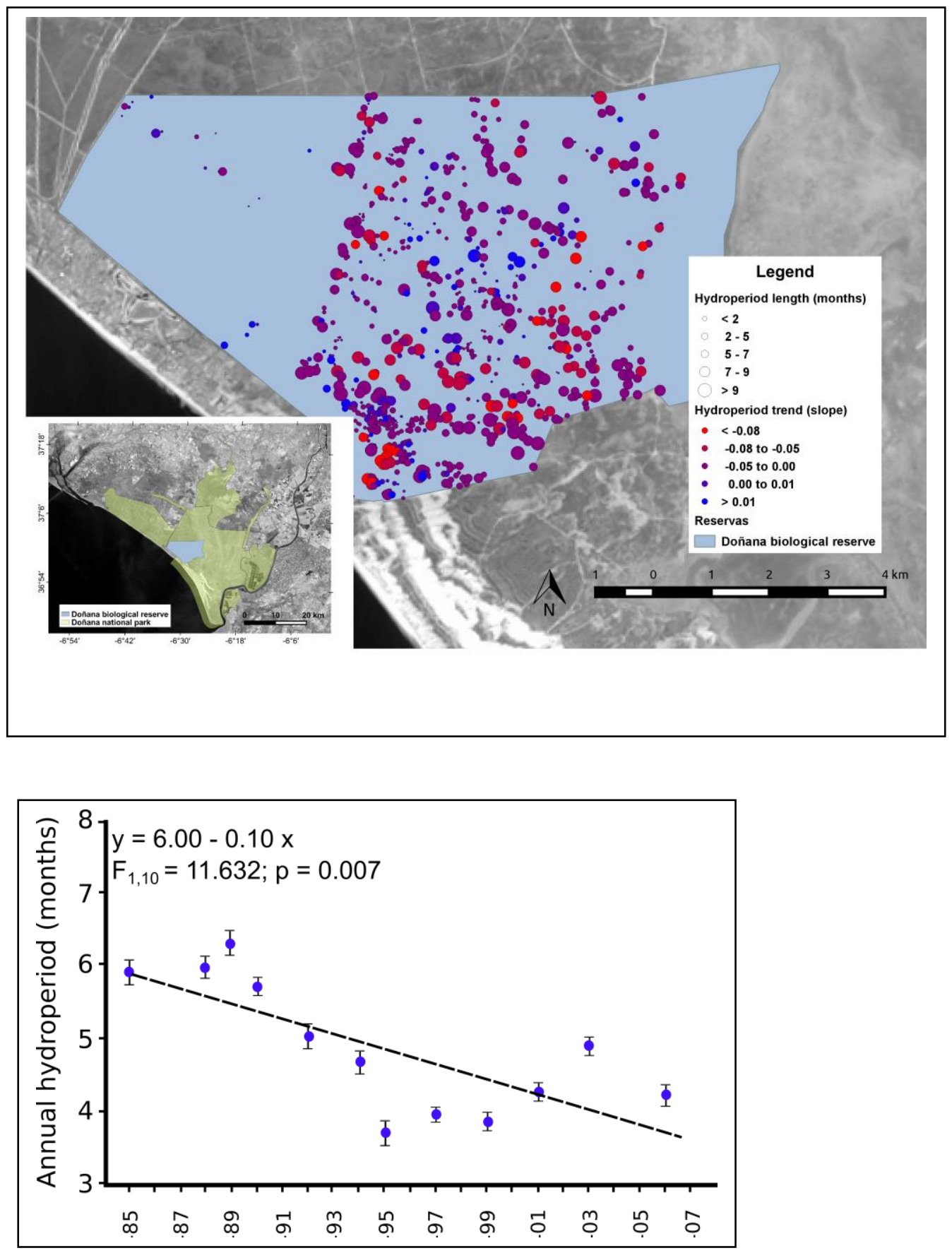

WebFigure 2. Average hydroperiod and decreasing trend for dune ponds from 1984 to 2007 (redrawn from Gómez-Rodríguez et al. 2010).

Gómez-Rodríguez C, Bustamante J, and Díaz-Paniagua C. 2010. Evidence of hydroperiod shortening in a preserved system of temporary ponds. Remote Sensing 2: 1439-62. 


\section{AJ Green et al. - Supporting Information}

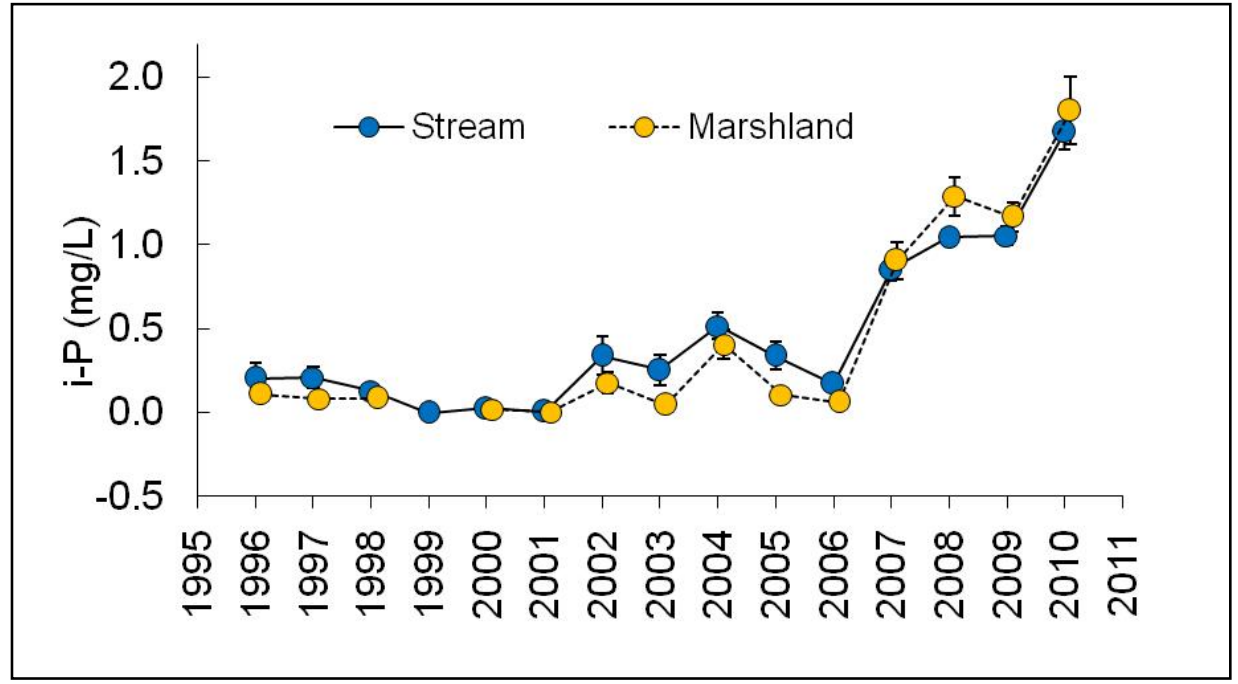

WebFigure 3. Increase in phosphorus $(P)$ in the Doñana National Park marsh and entry streams (from Espinar et al. 2015).

Espinar JL, Díaz-Delgado R, Bravo-Utrera MA, et al. 2015. Linking Azolla filiculoides invasion to increased winter temperatures in the Doñana marshland (SW Spain). Aquat Invasions 10: 17-24. 


\section{AJ Green et al. - Supporting Information}

\section{WebPanel 2. Summary of why Doñana World Heritage Site is such an important wetland complex}

\section{Important feature: avifauna}

Doñana became internationally famous in the 1950s primarily because of its enormous importance for waterbirds, which led to its protection. It holds a total of over 300 bird species at different times of year and more wintering waterfowl than any other site in Europe, and is the most important passage site for birds migrating between Europe and Africa along the Atlantic coast. It is very important for breeding waterbirds and raptors, which are also highly dependent on the aquatic ecosystems. Doñana is the source of expansion across Europe of several species such as the glossy ibis, which began to breed in Doñana in 1996 and by 2011 had over 8000 breeding pairs, whose progeny are creating new colonies in neighboring countries and dispersing widely as far as Scotland and the Caribbean islands.

\section{References}

Rendón et al. (2008); Sergio et al. (2011); Ramo et al. (2013); Santoro et al. (2016); SebastiánGonzález and Green (2016)

\section{Important feature: invertebrates}

Doñana is a general hotspot for aquatic diversity, including more than 110 species of aquatic Coleoptera, 42 Odonata species, 7 large branchiopods, 48 cladocerans, 20 cyclopoids, 13 diaptomids, 8 harpacticoids, 20 ostracods, and 74 rotifers. It also holds one species of rotifer and four flatworms that have not been recorded elsewhere.

\section{References}

Galindo et al. (1994); Millán et al. (2003); García-Novo and Marín-Cabrera (2005); Fahd et al. (2009); Van Steenkiste et al. (2011); Alcorlo et al. (2014); Florencio et al. (2014)

\section{Important feature: flora}

Doñana generally holds a highly diverse combination of European and Africa flora and fauna. Over 1300 vascular plants have been identified in the Doñana region, 170 of which are Iberian endemics and 60 of which are IUCN threatened. Eight species are unique to the Doñana region. Nearly 400 species are typical of Doñana wetlands (marsh and dune ponds), with 23 species that are Iberian endemics (eg Juncus emmanuelis, Rorippa valdes-bermejoi, Vulpia fontquerana, Micropyrosis tuberosa). Doñana also holds five diatoms not recorded elsewhere.

\section{References}

Valdés et al. (2007); Blanco et al. (2013); García-Murillo et al. (2014) 
Owing to their heterogeneity, the complex of 3000 temporary ponds in Doñana National Park is the most important in Europe. These ponds are highly variable in their hydroperiods and water chemistry, and are home to 11 species of amphibians as well as to three of the 24 species of reptiles and diatoms and rotifers endemic to Doñana. The largest ponds lie where mobile dunes meet stable sands and there is major discharge at the juncture between two aquifers.

\section{References}

Bravo-Utrera (2010); Díaz-Paniagua et al. (2010); Gómez-Rodríguez et al. (2009)

\section{Important feature: mobile dunes and the coastal belt of aeolian sands}

Doñana National Park holds the largest area of mobile dunes in Europe, included within the Abalario-Doñana coastal belt of aeolian sands. This belt is itself unique for its size, age, and origin from repeated sedimentary episodes. Five different strata extend from the mouth of the Guadalquivir Estuary, dating back to 70,000 years BCE.

\section{References}

Rodríguez Vidal et al. (2014); Vallejo Villalta (2007); Zazo et al. (2011)

\section{Important feature: human history}

Doñana has been important to humans since it was occupied by Neolithic populations around 5500 BCE. It was occupied by the Romans, then later by members of Muslim and Christian royalty. From the end of the Moorish occupation until the end of the 19th century it belonged to the Medina Sidonia family, and was the site of several hunting lodges visited by nobility and aristocrats from all over Spain. Francisco de Goya may have painted some of his most important portraits there. An international campaign to save Doñana in the face of development plans led to the establishment of the World Wildlife Fund in 1961. The Doñana Biological Reserve was established in 1964, and the National Park was created in 1969 then extended repeatedly in 1978, 2004, and 2014. Since the transition to democracy after Franco's death, Doñana has been used by successive presidents to hold international summits and to take holidays.

References

Asiaín et al. (2008); Mendez et al. (2012)

\section{WebReferences}

Alcorlo P, Jimenez S, Baltanas A, et al. 2014. Assessing the patterns of the invertebrate community in the marshes of Doñana National Park (SW Spain) in relation to environmental factors. Limnetica 33: 189-204.

Asiaín A, Hernández E, and Vega I. 2008. 40 años en Doñana. Historia del Parque Nacional y WWF. Panda 104: 8-15. 
Blanco S, Alvarez-Blanco I, Cejudo-Figueiras C, et al. 2013. The diatom flora in temporary ponds of Doñana National Park (southwest Spain): five new taxa. Nord J Bot 31: 489-99.

Bravo-Utrera MA. 2010. Monitoring aquatic ecosystems at Doñana Natural Space. In: Hurford C, Schneider M, and Cowx I (Eds). Conservation monitoring in freshwater habitats: a practical guide and case studies. Dordrecht, the Netherlands: Springer Science.

Díaz-Paniagua C, Fernandez-Zamudio R, Florencio M, et al. 2010. Temporary ponds from Doñana National Park : a system of natural habitats for the preservation of aquatic flora and fauna. Limnetica 29: 41-58.

Fahd K, Arechederra A, Florencio M, et al. 2009. Copepods and branchiopods of temporary ponds in the Doñana Natural Area (SW Spain): a four-decade record (1964-2007). Hydrobiologia 634: 219-30.

Florencio M, Diaz-Paniagua C, Gomez-Rodriguez C, et al. 2014. Biodiversity patterns in a macroinvertebrate community of a temporary pond network. Insect Conserv Divers 7: 4-21.

Galindo MD, Serrano L, Segers H, et al. 1994. Lecane-donyanaensis n-sp (rotifera, monogonanta, lecanidae) from the Doñana-National-Park (Spain). Hydrobiologia 284: 235-39.

Garcia-Murillo P, Bazo E, and Fernandez-Zamudio R. 2014. Las plantas de la marisma del Parque Nacional de Doñana (España): elemento clave para la conservación de un humedal europeo paradigmático. Ciencia UAT 9: 61-75.

García-Novo F and Marín-Cabrera C. 2005. Doñana, water and biosphere. Madrid, Spain: Confederación Hidrográfica del Guadalquivir, Ministerio de Medio Ambiente. http://issuu.com/pubcipriano/docs/donanawaterandbiosphere_2005_.

Gómez-Rodríguez C, Diaz-Paniagua C, Serrano L, et al. 2009. Mediterranean temporary ponds as amphibian breeding habitats: the importance of preserving pond networks. Aquatic Ecol 43: 1179-91.

Mendez PF, Isendahl N, Amezaga JM, et al. 2012. Facilitating transitional processes in rigid institutional regimes for water management and wetland conservation: experience from the Guadalquivir estuary. Ecol Soc 17: 26.

Millán A, Hernando C, Aguilera P, et al. 2003. Los coleópteros acuáticos y semiacuáticos de Doñana: reconocimiento de su biodiversidad y prioridades de conservación. Boletin Sociedad Entomológica Aragonesa 36: 157-64.

Ramo C, Aguilera E, Figuerola J, et al. 2013. Long-term population trends of colonial wading birds breeding in Doñana (SW Spain) in relation to environmental and anthropogenic factors. Ardeola 60: 305-26.

Rendón MA, Green AJ, Aquilera E, et al. 2008. Status, distribution and long-term changes in the waterbird community wintering in Doñana, south-west Spain. Biol Conserv 141: 1371-88.

Rodríguez Vidal J, Bardají T, Zazo C, et al. 2014. Coastal dunes and marshes in Doñana National Park. In: Gutiérrez F and Guttiérrez M (Eds). Landscapes and landforms of Spain. Dordrecht, the Netherlands: Springer Science.

Santoro S, Green AJ, and Figuerola J. 2016. Immigration enhances fast growth of a newlyestablished source population. Ecology 97: 1048-57.

Sebastián-González E and Green AJ. 2016. Reduction of avian diversity in created versus natural and restored wetlands. Ecography 39: 1176-84.

Sergio F, Blas J, Lopez L, et al. 2011. Coping with uncertainty: Breeding adjustments to an unpredictable environment in an opportunistic raptor., Oecologia 166: 79-90.

Valdés B, Girón V, Sánchez Gullón E, et al. 2007. Catálogo florístico del espacio natural de Doñana (SO de España). Plantas vasculares. Lagascalia 27: 73-362.

Vallejo Villalta I. 2007. Caracterización geomorfológica y análisis de la evolución reciente del sistema de dunas activas del P.N de Doñana 1956-2001 (PhD dissertation). Sevilla, Spain: Universidad de Sevilla.

Van Steenkiste N, Tessens B, Krznaric K, et al. 2011. Dalytyphloplanida (Platyhelminthes: Rhabdocoela) from Andalusia, Spain, with the description of four new species. Zootaxa 2791: 1-29.

Zazo C, Dabrio CJ, Goy JL, et al. 2011. El complejo eólico de El Abalario (Huelva). In: Sanjaume Saumell E and Gracia Prieto FJ (Eds). Las dunas en España. Puerto Real: Sociedad Española de Geomorfología. 
WebTable 1. Sources of information for Panel 1

\begin{tabular}{|l|l|}
\hline Wetland & Sources \\
\hline Tablas de Daimiel & Navarro et al. (2011); Álvarez-Cobelas (2010); Aguilera et al. (2013); Vidal et al. (2013) \\
\hline Lac Ichkeul & Ramdani et al. (2001); Hamdi et al. (2008, 2012) \\
\hline Lake Koronia & Mitraki et al. (2004); Manakou et al. (2013); Mediterranean Wetlands Observatory (2014) \\
\hline Azraq Oasis & $\begin{array}{l}\text { Halls (1997); Fariz and Hatough-Bouran (1998); Prochazka } \text { et al. (2008); Kloub et al. } \\
\text { (2010); Woolfenden and Ababneh (2011); Mir and Hamidan (2012); Kaudse } \text { et al. } \text { (2014) }\end{array}$ \\
\hline Sultansazligi & Karadeniz (2000); Ozesmi and Gürer (2004); Dadaser-Celik et al. (2008, 2009) \\
\hline
\end{tabular}

\section{WebReferences}

Aguilera H, Castano S, Moreno L, et al. 2013. Model of hydrological behaviour of the anthropized semiarid wetland of las Tablas de Daimiel National Park (Spain) based on surface watergroundwater interactions. Hydrogeol J 21: 623-41.

Álvarez-Cobelas M. 2010. Fish and avian communities: a testimony of wetland degradation. In: SánchezCarrillo S and Angeler DG (Eds). Ecology of threatened semi-arid wetlands: long-term research in Las Tablas de Daimiel. Dordrecht, the Netherlands: Springer Science.

Dadaser-Celik F, Bauer ME, Brezonik PL, et al. 2008. Changes in the Sultan Marshes ecosystem (Turkey) in satellite images 1980-2003. Wetlands 28: 852-65.

Dadaser-Celik F, Coggins JS, Brezonik PL, et al. 2009. The projected costs and benefits of water diversion from and to the Sultan Marshes (Turkey). Ecol Econ 68: 1496-506.

Fariz GH and Hatough-Bouran A. 1998. Case study: Jordan. Population dynamics in arid regions: the experience of the Azraq Oasis Conservation Project. In: de Sherbinin A and Dompka V (Eds). Water and population dynamics: case studies and policy implications. Washington, DC: American Association for the Advancement of Science.

Halls AJ. 1997. Wetlands, biodiversity and the Ramsar Convention: the role of the Convention on Wetlands in the conservation and wise use of biodiversity. Gland, Switzerland: Ramsar Convention Bureau.

Hamdi N, Charfi F, and Moali A. 2008. Variation of the waterbird community relying to the Ichkeul National Park, Tunisia. Eur J Wildlife Res 54: 417-24.

Hamdi N, Touihri M, and Charfi F. 2012. Ecological diagnosis of the Ichkeul National Park (Tunisia) after dams building: the case of waterbirds. Rev Ecol-Terre Vie 67: 41-62.

Karadeniz N. 2000. Sultansazligi, Ramsar site in Turkey. Humedales Mediterráneos 1: 107-14.

Kaudse T, Bani-Khalaf R, Tuffaha R, et al. 2016. Noble gases reveal the complex groundwater mixing pattern and origin of salinization in the Azraq Oasis, Jordan. Applied Geochemistry 66: 114-128.

Kloub N, Matouq M, Krishan M, et al. 2010. Multitemporal monitoring of water resources degradation at Al-Azraq Oasis, Jordan, using remote sensing and GIS techniques. Int J Global Warm 2: 1-16.

Manakou V, Tsiakis P, and Kungolos A. 2013. A mathematical programming approach to restore the water balance of the hydrological basin of Lake Koronia. Desalin Water Treat 51: 2955-76.

Mediterranean Wetlands Observatory. 2014. Land cover - spatial dynamics in Mediterranean coastal wetlands from 1975 to 2005. Thematic collection, issue 2. Le Sambuc, France: Tour du Valat.

Mir S and Hamidan N. 2012. The current status of indigenous freshwater fishes in Jordan. Bangladesh J Zool 40: 59-67.

Mitraki C, Crisman TL, and Zalidis G. 2004. Lake Koronia, Greece: shift from autotrophy to heterotrophy with cultural eutrophication and progressive water-level reduction. Limnologica 34: 110-16.

Navarro V, Garcia B, Sanchez D, et al. 2011. An evaluation of the application of treated sewage effluents in las Tablas de Daimiel National Park, central Spain. J Hydrol 401: 53-64.

Ozesmi U and Gürer I. 2004. Sultan Sazligi: biodiversity and natural resources management pilot project in Turkey (GEF-II). In: Assessment and provision of environmental flows in Mediterranean watercourses. Malaga, Spain: IUCN Mediterranean Office.

Procházka P, Bellinvia E, Fainová D, et al. 2008. Immigration as a possible rescue of a reduced population of a long-distant migratory bird: Reed warblers in the Azraq Oasis, Jordan. J Arid Environ 72: 1184-92.

Ramdani M, Flower RJ, Elkhiati N, et al. 2001. North African wetland lakes: characterization of nine sites included in the Cassarina project. Aquat Ecol 35: 281-302.

Vidal D, Anza I, Taggart MA, et al. 2013. Environmental factors influencing the prevalence of Clostridium botulinum type C/D mosaic strain in nonpermanent Mediterranean wetlands. Appl Environ Microbiol 79: 4264-71.

Woolfenden WB and Ababneh L. 2011. Late Holocene vegetation in the Azraq wetland reserve, Jordan. Quaternary Res 76: 345-51. 